\title{
Transcriptome profiling in Camellia japonica var. decumbens for the discovery of genes involved in chilling tolerance under cold stress
}

\author{
Yawen Wu', Markus Müller², Tian Bai', Shunyang Yao', Oliver Gailing², Zhen Liu's
}

Wu Y., Müller M., Bai T., Yao S., Gailing O., Liu Z., 2019. Transcriptome profiling in Camellia japonica var. decumbens for the discovery of genes involved in chilling tolerance under cold stress. Ann. For. Res. 62(1): - .

Abstract. Camellia japonica var. decumbens is a naturally occurring highly cold resistant variety of Camellia japonica which is suitable for snowy and cold regions. However, the underlying cold-adaptive mechanisms associated with gene regulation have been poorly investigated. We analyzed the transcriptomic changes caused by cold stress in a cold-tolerant accession. Samples were collected at the end of each temperature treatment $(\mathrm{T} 1, \mathrm{~T} 3$, T5, T7 and T9 represent the temperatures $25^{\circ} \mathrm{C}, 0^{\circ} \mathrm{C},-4^{\circ} \mathrm{C},-8^{\circ} \mathrm{C}$ and $-12^{\circ} \mathrm{C}$, respectively). Sample $\mathrm{T} 1$ at $25^{\circ} \mathrm{C}$ was used as control. Based on transcriptome analysis, 2828, 2384, 3099 and 3075 differentially expressed genes (DEGs) were up-regulated, and 3184, 2592, 2373 and 2615 DEGs were down-regulated by analyzing T3/T1, T5/T1, T7/T1 and T9/T1, respectively. A gene ontology (GO) analysis revealed an enrichment of GO terms such as response to stimulus, metabolic process, catalytic activity or binding. Out of the larger number of DEGs, 67 functional and regulatory DEGs stood out, since they were functionally characterized in other models. These genes are cold-responsive transcription factors (26) or involved in cold sensor or signal transduction (17) and in the stabilization of the plasma membrane and osmosensing response (24). These results suggest rapid and multiple molecular mechanisms of perception, transduction and responses to cold stress in cold acclimation of Camellia japonica var. decumbens. They could also serve as a valuable resource for relevant research on cold-tolerance and help to explore cold-related genes to foster the understanding of low-temperature tolerance and plant-environment interactions.

Keywords: transcriptome profiling, Camellia japonica var. decumbens, differentially expressed genes, cold-responsive genes, transcription factors

Authors. ${ }^{1}$ College of Forestry, Henan Agricultural University, 450002, Zhengzhou, China $\mid{ }^{2}$ University of Göttingen, Forest Genetics and Forest Tree Breeding, Büsgenweg 2, 37077 Göttingen, Germany

$\S$ Corresponding author: Zhen Liu (liuzh20@163.com)

Manuscript received January 28, 2019; revised May 11, 2019; accepted May 25, 2019; online first June 27, 2019. 


\section{Introduction}

Low temperature is one of the major environmental factors limiting the growth, development and geographical distribution of plants (Thomashow 1999). Stress caused by low temperature can be divided into chilling stress $\left(0-15^{\circ} \mathrm{C}\right)$ and freezing stress $\left(<0^{\circ} \mathrm{C}\right)$. Tropical and subtropical cold-sensitive plants lack an antifreeze mechanism, cannot survive freezing temperatures, show sensitivity to low temperatures above the freezing point and are vulnerable to chilling injury (Tan et al. 2016). Plants from temperate regions show different degrees of cold tolerance, and exposure to moderate frost stress can improve frost resistance, ensuring that the plant can survive cold temperatures during winter; this process is generally known as an antifreeze mechanism, and the plant's ability to adapt to low temperatures below the freezing point is called frost resistance.

Camellia is concentrated in the eastern and southeast Asian regions of $\mathrm{S} 7^{\circ}-\mathrm{N} 35^{\circ}$ and $\mathrm{E}$ $80^{\circ}-\mathrm{E} 140^{\circ}$, including Japan, the Himalayas, Indonesia, Java and Sumatra (Min and Zhang 1996; Kondo 2008). Camellia japonica L. is an evergreen broad-leaved woody species that is widely distributed in Japan and along the southern and western coasts of the Korean Peninsula as an ornamental plant. Flowering may occur from October to May but is most common from January to March. C. japonica oil has been used as a cosmetic protectant for healthy skin and hair and as a soothing agent (Kim et al. 2012). In addition, the flower petals and buds of $C$. japonica have been used in treatment for bleeding and blood stagnation, as well as in traditional oriental medicine due to their anti-inflammatory properties (Yoshikawa et al. 2007, Piao et al. 2011). Because the distribution of this plant is generally limited by low temperatures, the distribution area of Camellia is concentrated in temperate and subtropical regions at low latitudes. The plant is difficult to cultivate in open fields at high latitudes, which limits the ornamental and economic value of Camellia. C. japonica var. decumbens is a naturally occurring variety of $C$. japonica which is primarily distributed in the Akita and Shiga prefectures in Iwate $\left(39^{\circ} \mathrm{N}\right)$, Japan. This variety is suitable for snowy and cold zones and has a strong cold resistance (Lin 1994). At present, in Japan, it is distributed in the Iwate prefecture in the north with the snowy Japan Sea climate in winter, the Ise plain in the east with the East Sea climate, and in the Mie prefecture with a warmer climate and moderate snowfall in winter. Therefore, $C$. japonica var. decumbens is an ideal cold-resistant germplasm resource.

With the advent and further development of high-throughput sequencing technologies, more crops have been assessed in transcriptome studies, and significant progress has been made in revealing cold response mechanisms and key regulator genes. For example, Tan et al. (2016) and Xu et al. (2014) investigated the cold response mechanisms of the cold-sensitive plant asparagus bean (Vigna unguiculata subsp. sesquipedalis) and the extremely cold-tolerant Chinese wild Vitis species by RNA-seq and explored cold stress-related candidate genes. Wang et al. (2016) studied the transcriptome response of apple dwarfing rootstocks to cold stress and revealed cold injury mechanisms of apple. Wang et al. (2013) studied the transcriptome response of Camellia sinensis to cold stress and identified related candidate genes. Finally, Li et al. (2016) investigated a cold acclimation-related transcriptome of a cold tolerant $C$. japonica cultivar.

Although both 1-year-old herbs and perennial woody plants have low-temperature mechanisms, woody plants have the ability to survive long periods of low temperature, extremely low temperatures, and intra-tissue icing, while 1 -year-old herbs often do not have this ability. Therefore, elucidating the physiological and molecular mechanisms underlying the survival of woody plants under cold stress and freezing stress is not only a major scientific prob- 
lem that requires urgent solutions but also has important economic significance. This study used C. japonica var. decumbens distributed in Japan's northernmost regions as experimental materials to study the transcriptome under different cold stress and aimed to explore the molecular mechanisms of cold tolerance in $C$. japonica var. decumbens to provide a reference for applications in production and breeding.

\section{Materials and methods}

\section{Plant materials and cold treatment}

Four-year-old potted $C$. japonica var. decumbens seedlings from a population in Morioka, Japan were planted at a test site of Henan Agricultural University, Zhengzhou, China. The plants (more than 100) were grown under natural conditions. Low semi-lethal temperatures (LT50) were calculated using the electric conductivity (Xu and Chen 2008) and logistic equations (Gai 2000) in C. japonica var. decumbens leaves. The freezing test temperature was set to the $C$. japonica var. decumbens LT50. For cold treatments, plants $(\mathrm{n}=20)$, which had a uniform growth status, were transferred to a climate chamber (cooling rate of $2^{\circ} \mathrm{C} / \mathrm{h}$ ) with constant light (cool-white fluorescent light, at approximately $100 \mu \mathrm{mol} \mathrm{m} \mathrm{m}^{-2} \mathrm{~s}^{-1}$ ) to achieve uniform conditions. The cooling temperature mode of the culture was as follows: $25^{\circ} \mathrm{C} / 15 \mathrm{~d}$, $\sim 20^{\circ} \mathrm{C} / 1 \mathrm{~d}, \sim 15^{\circ} \mathrm{C} / 1 \mathrm{~d}, \sim 10^{\circ} \mathrm{C} / 1 \mathrm{~d}, \sim 5^{\circ} \mathrm{C} / 1 \mathrm{~d}, \sim$ $0^{\circ} \mathrm{C} / 2 \mathrm{~h}, \sim-4^{\circ} \mathrm{C} / 2 \mathrm{~h}, \sim-8^{\circ} \mathrm{C} / 2 \mathrm{~h}$ and $\sim-12^{\circ} \mathrm{C} / 2$ h. Samples were collected at the end of each temperature treatment ( $\mathrm{T} 1, \mathrm{~T} 3, \mathrm{~T} 5, \mathrm{~T} 7$ and $\mathrm{T} 9$ represent the temperatures $25^{\circ} \mathrm{C}, 0^{\circ} \mathrm{C},-4^{\circ} \mathrm{C}$, $-8^{\circ} \mathrm{C}$ and $-12^{\circ} \mathrm{C}$, respectively). Sample $\mathrm{T} 1$ at $25^{\circ} \mathrm{C}$ was used as control. Samples comprising mature and healthy leaves were harvested and pooled at the various temperatures. In total, 10 leaves were collected from the samples at each temperature point. These collected samples were washed with distilled deionized water, frozen in liquid nitrogen and stored at $-80^{\circ} \mathrm{C}$.

\section{RNA extraction and quality determination}

\section{RNA extraction}

Total RNA was extracted with plant RNA Reagent (Invitrogen, Cat. No. 12322-012) following the manufacturer's protocol. The quality of RNA was determined using a NanoDrop ND-1000 spectrophotometer (Thermo Fisher Scientific, MA, USA). RNA integrity was confirmed by electrophoresis on a $1.5 \%$ agarose gel.

\section{Library construction and sequencing}

Approximately $20 \mu \mathrm{g}$ of total RNA from each of five pooled samples (T1, T3, T5, T7 and T9) was used for Illumina sequencing at Biomarker Technologies (Beijing, China). cDNA library construction was performed via the following steps. First, mRNA was purified with biotin-oligo (dT) magnetic beads and randomly sheared using a Fragmentation Buffer (NEB, USA). Second, these sheared fragments were used as a template for cDNA synthesis. First-strand cDNA was synthesized with random hexamers, and then, buffer, dNTPs, RNase $\mathrm{H}$ and DNA polymerase I were added to synthesize second-strand cDNA, the product of which was purified with AMPure XP beads. Furthermore, purified double-strand cDNA was end-repaired, combined with poly-A tails and ligated to an Illumina adapter. Then, AMPure XP beads were used to select fragment sizes $(150 \sim 200 \mathrm{bp})$. Finally, cDNA libraries were obtained by PCR enrichment. In total, we constructed four paired-end libraries, and sequencing of the purified libraries was carried out on a HiSeq2000 system (Illumina Inc., USA).

\section{Data analysis}

After Illumina sequencing, raw reads were first edited by trimming adapters and removing low-quality sequences. As a result, high-quali- 
ty reads, which were called "clean reads", were obtained. De novo assembly of clean reads from four libraries was performed collectively with Trinity (release 20131110) (Grabherr et al. 2011) to establish a single set of non-redundant unigenes. After assembly, unigenes were compared to the NR (Deng et al. 2006), SwissProt (Apweiler et al. 2004), GO (Ashburner et al. 2000), COG (Tatusov et al. 2000), KOG (Koonin et al. 2004) and KEGG (Kanehisa et al. 2004) databases using BLAST (Altschul et al. 1997) with a cut-off E-value of $\leq 10^{-5}$. Moreover, using the HMMER software (Eddy 1998) with an E-value threshold of $\leq 10^{-10}$, amino acid sequences translated from the unigenes were aligned to the Pfam database (Finn et al. 2014) to gather information about the function and structure of the unigene proteins.

To obtain assembly statistics for the percentage of reads that could be mapped back to transcripts (mapped ratio), we used bowtie (version 1.1.1) (Langmead et al. 2009) to align short reads to the transcripts. According to the results, transcript abundance was estimated with RSEM (version 1.2.3) (Li and Dewey 2011). FPKM (Fragments Per Kilobase of transcript per Million mapped reads) (Trapnell et al. 2010) was used to quantify the expression level of unigenes. FPKM/RPKM (Mortazavi et al. 2008) is currently the most popular method for normalizing RNA-seq gene expression. FPKM is computed similar to RPKM, but it accounts for the scenario in which only 1 end of a pair-end read is mapped (Guo et al. 2013). This value can be directly applied to compare gene expression levels among samples. FPKM is calculated as follows:

FPKM $=\frac{\text { cDNA Fragments }}{\text { Mapped Fragments (Millions) } \times \text { Transcript Length }(\mathrm{kb})}$

In this formula, cDNA fragments are the number of reads that align to a specific unigene, mapped fragments (millions) are the total number of reads that align to unigenes, and transcript length $(\mathrm{kb})$ is the length of the unigene.

\section{Identification of differentially expressed genes (DEGs)}

DEGs between cold-treated and control samples (T1) were identified by EBSeq (Version 1.6.0) (Leng et al. 2013) based on a rigorous algorithm developed by Audic and Claverie (Audic and Claverie 1997). The False Discovery Rate (FDR) control method (Reiner et al. 2003) was applied in multiple hypothesis testing to correct the results for the $p$ value. An "FDR $<0.01$ and FC (fold change) $\geq 4$ " was set as the threshold to determine the significance of gene expression differences. FC represents the ratio of FPKM between cold-treated and control samples. Finally, the Mercator tool (Lohse et al. 2014) was employed to analyze these DEGs for functional annotation and classification.

\section{Results}

The relative conductivities of $C$. japonica var. decumbens at $0^{\circ} \mathrm{C},-4^{\circ} \mathrm{C},-8^{\circ} \mathrm{C},-12^{\circ} \mathrm{C},-16^{\circ} \mathrm{C}$, and $-20^{\circ} \mathrm{C}$ were $18.6 \%, 20.6 \%, 28.8 \%, 52.6 \%$, $69.6 \%$, and $75.2 \%$, respectively. The relative conductivity of $C$. japonica var. decumbens was analyzed by the logistic equation for regression analysis, and the inflection point temperature was used to determine the LT50 of the leaves. The LT50 of C. japonica var. decumbens was determined to be $-11.93^{\circ} \mathrm{C}$. The fit of the equation, $\mathrm{R}^{2}$, was 0.9477 , indicating the relative conductivity. The change is consistent with the changing rule of the logistic equation and is a good fit. Based on the results of this experiment, the lowest temperature of the climate chamber was set to $-12^{\circ} \mathrm{C}$.

\section{Illumina sequencing, de novo assembly and annotation}

In total, 136.709 million reads and a Q30 percentage (percentage of sequences with sequencing error rate lower than $0.1 \%$ ) over $92 \%$ 
were generated (Table 1). Finally, short reads were assembled into 94,771 unigenes, with a mean length of $770 \mathrm{bp}$ and N50 length of 1071 bp (Table 2). Eventually, a total of 44,929 $(47.41 \%)$ of the unigenes were annotated. The T1 vs T 5 comparison group had the least DEGs (2909), and the number of genes that obtained annotation information in at least one database was 759 , while the T1 vs T3 comparison group had the largest number of DEGs (3405), of which 908 were annotated in at least one database. Statistics and detailed annotation of the unigenes are presented in Table 3.

\section{Gene expression level evaluation}

The expression level detected by RNA-seq is highly sensitive. Normally, the FPKM of genes encoding proteins ranged from $10^{-2}$ to $10^{4}$ (Djebali et al. 2012). The overall distribution of the gene expression levels of the five libraries is shown in Fig. 1, suggesting that the alteration of gene expression is more obvious in cold-treated samples of C. japonica var. decumbens than in controls.

\section{Defining DEGs under cold stress}

At each temperature point, we detected both unique and overlapping sets of DEGs. As shown in Fig. 2a, 2828, 2384, 3099 and 3075 DEGs were up-regulated, and 3184, 2592, 2373 and 2615 DEGs were down-regulated by analyzing T3/T1, T5/T1, T7/T1 and T9/

Table 1 Summary for RNA-seq datasets of C. japonica var. decumbens

\begin{tabular}{lllll}
\hline Samples & Read Number (million) & Base Number $(\mathrm{Gb})$ & GC Content & $\% \geq \mathrm{Q} 30$ \\
\hline T 1 & 30.773 & 9.069 & $44.91 \%$ & $93.06 \%$ \\
\hline T 3 & 28.841 & 8.482 & $45.21 \%$ & $93.44 \%$ \\
\hline T 5 & 26.601 & 7.868 & $45.48 \%$ & $93.22 \%$ \\
\hline T 7 & 24.223 & 7.138 & $45.75 \%$ & $93.34 \%$ \\
\hline T 9 & 26.271 & 7.725 & $45.47 \%$ & $92.92 \%$ \\
\hline
\end{tabular}

Table 2 Length distribution of assembled unigenes

\begin{tabular}{llr}
\hline Unigene length $(\mathrm{bp})$ & Number of sequences & Proportion (\%) \\
\hline $200-300$ & 18802 & 19.84 \\
\hline $300-500$ & 29317 & 30.93 \\
\hline $500-1000$ & 26946 & 28.43 \\
\hline $1000-2000$ & 13000 & 13.72 \\
\hline $2000+$ & 6706 & 7.08 \\
\hline Total Number & 94771 & \\
\hline Mean Length & $770 \mathrm{bp}$ & \\
\hline N50 Length & $1071 \mathrm{bp}$ & \\
\hline
\end{tabular}

Note. Length range: indicates the different length ranges of unigenes; the number in the table indicates the number of unigenes in the corresponding interval, and the percentage indicates the proportion of unigenes in the corresponding length interval. Total number: indicates the total number of unigenes assembled. Mean Length: represents the average length of the unigenes. N50 Length: represents the length of the unigene's N50. 
Table 3 Quantitative statistics of annotated differentially expressed genes

\begin{tabular}{lllllllllr}
\hline DEG_Set & Annotated & COG & GO & KEGG & KOG & Pfam & Swiss-Prot & eggNOG & nr \\
\hline T1 vs T3 & 3405 & 908 & 1845 & 969 & 1757 & 2358 & 2324 & 3132 & 3367 \\
\hline T1 vs T5 & 2909 & 759 & 1571 & 835 & 1507 & 2037 & 1997 & 2690 & 2876 \\
\hline T1 vs T7 & 3218 & 838 & 1770 & 901 & 1609 & 2264 & 2213 & 2969 & 3184 \\
\hline T1 vs T9 & 3277 & 821 & 1781 & 918 & 1625 & 2276 & 2238 & 3011 & 3236 \\
\hline
\end{tabular}

Note. DEG_Set, differentially expressed gene set name; Annotated, annotated number of differentially expressed genes. Third to last column indicate the number of differentially expressed genes annotated by each functional database.

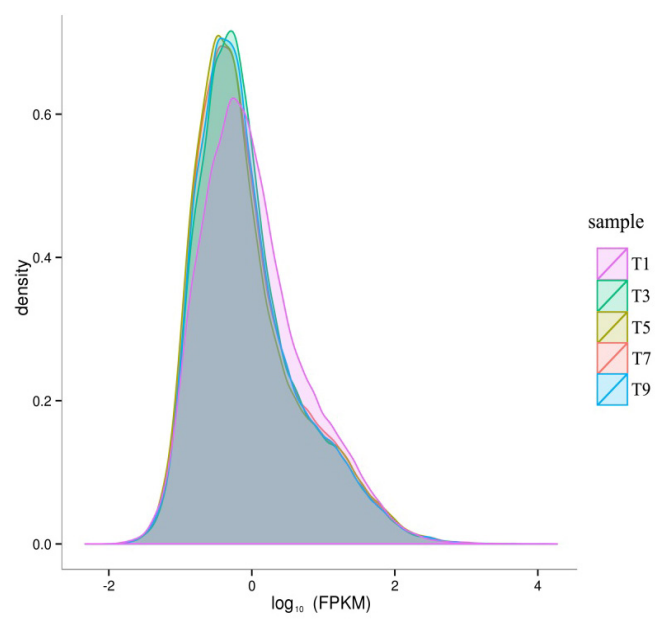

Figure 1 The FPKM density of each sample

T1, respectively. A total of 8907 DEGs, including 4823 cold-inducible and 4084 cold-repressed genes, were identified in our RNA-seq data. In addition, 1387 up-regulated and 1628 down-regulated genes were simultaneously detected at all five temperatures. To further explore the expression profiles of overlapping genes, we generated a heat map representing the transcript levels for these transcripts at T1, T3, T5, T7 and T9 (Fig. 2b). These DEGs could be categorized into two clusters: genes in cluster A were rapidly up-regulated in response to cold stress, and cluster B genes were repressed during the cold treatment. The above analysis indicated that more genes were activated than repressed during the cold process.

\section{GO annotation analysis of DEGs}

Annotated unigenes could be divided into the 3 GO categories: biological processes, cellular components, and molecular functions. These three categories contain 21, 17 and 16 functional subclasses. Metabolic processes, cellular process, response to stimulus, and single-organism processes were highly expressed within the biological process category. Most of the genes categorized under molecular function were involved in catalytic activity, binding and transporter activity. Cell parts, cells, and organelles occupied the top three categories of cell components.

We performed the enrichment analysis for GO terms in $3 \mathrm{GO}$ categories separately for the different temperature treatments. GO terms with highest significance in the biological processes in all treatments were "oxidation-reduction process" (GO:0055114), "myo-inositol hexakisphosphate biosynthetic process" (GO:0010264) and "photosystem II assembly" (GO:0010207). Among cell components, most significantly enriched GO terms were "chloroplast" (GO:0009507), "plastoglobule" (GO:0010287) and "extracellular region" (GO:0005576). GO terms with highest significance in the molecular function category were "monooxygenase activity" (GO:0004497), "heme binding" (GO:0020037) and "transmembrane receptor protein tyrosine kinase activity" (GO:0004714) (Fig. 3). 
(a)

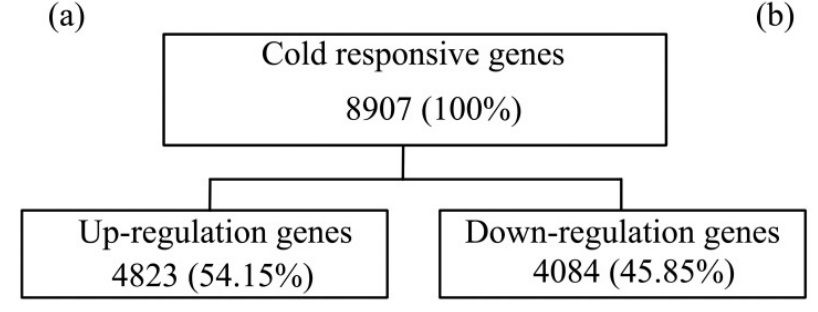

T1 VS T3, 2828

T1 VS T5, 2384

T1 VS T3, 3184

T1 VS T3, 2592

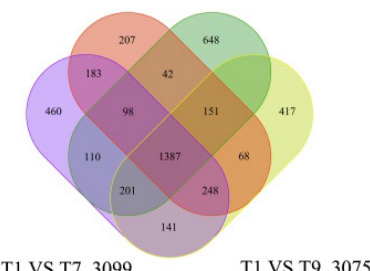

T1 VS T7, 3099

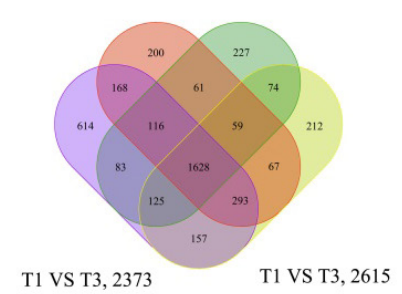

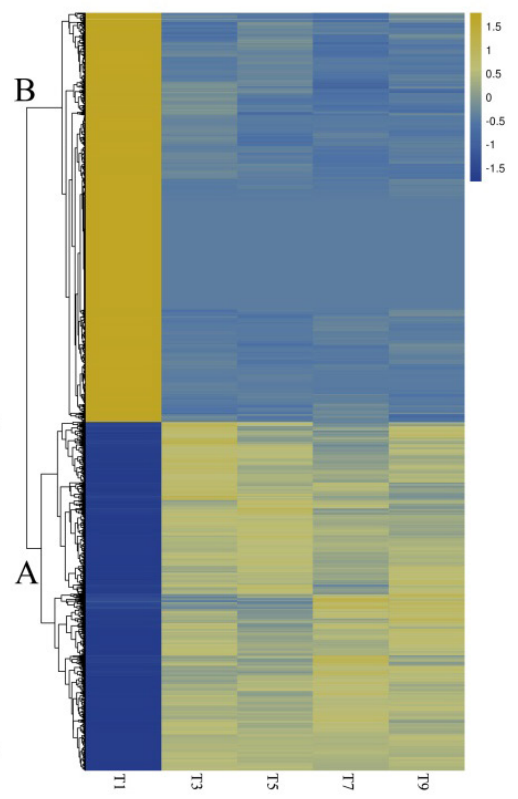

Figure 2 Expression profiling of cold-regulated DEGs in C. japonica var. decumbens leaves. (a) Venn diagrams representing the numbers of DEGs and the overlaps of sets obtained across four comparisons. The library from the $25^{\circ} \mathrm{C}$ pooled samples was used as a calibrator to normalize the DEGs in the other four cold-stressed libraries. Percentages in parentheses were calculated with the total numbers of cold-regulated genes (8907). Diagrams in rectangles indicate cold treatment temperature and total number of cold-regulated DEGs at the indicated points. (b) Hierarchical cluster heat map and cluster tree from the overlapping genes, A: up-regulated in response to cold stress, B: down-regulated in response to cold stress.

\section{Functional genes involved in cold stress}

DEGs with key functional roles in cold stress response: cold sensor or signal transduction genes (Table S1 - Supporting Information), genes related to the stabilization of the plasma membrane and osmosensing response (Table S2 - Supporting Information) and cold-responsive transcription factors (TF) (Table S3 - Supporting Information) are described in detail below.

\section{Cold sensor or signal transduction genes}

In this study, 14 genes (Table 4) were annotated as CBL-interacting protein kinase $(C I P K)$, cysteine-rich RECEPTOR-like protein kinase
$(C R K)$, calmodulin, calcium-binding and phospholipase proteins which were shown to be involved in signal transduction upon low-temperature stress. Among these genes, 9 (5 CIPKs, 2 CRKs, 1 phospholipase gene and 1 calcium-binding protein) were up-regulated, whereas 5 (1 CIPK, 1 CRK, 1 phospholipase gene, 1 calmodulin and 1 calcium-binding protein) were down-regulated.

\section{Genes related to the stabilization of the plas- ma membrane and osmosensing response}

In our study, we found 3 anti-freezing proteins $(A F P S)$ that maintain plasma membrane stability, 9 carbohydrate-related and 10 osmotic regulation substances (Table 5). The three 


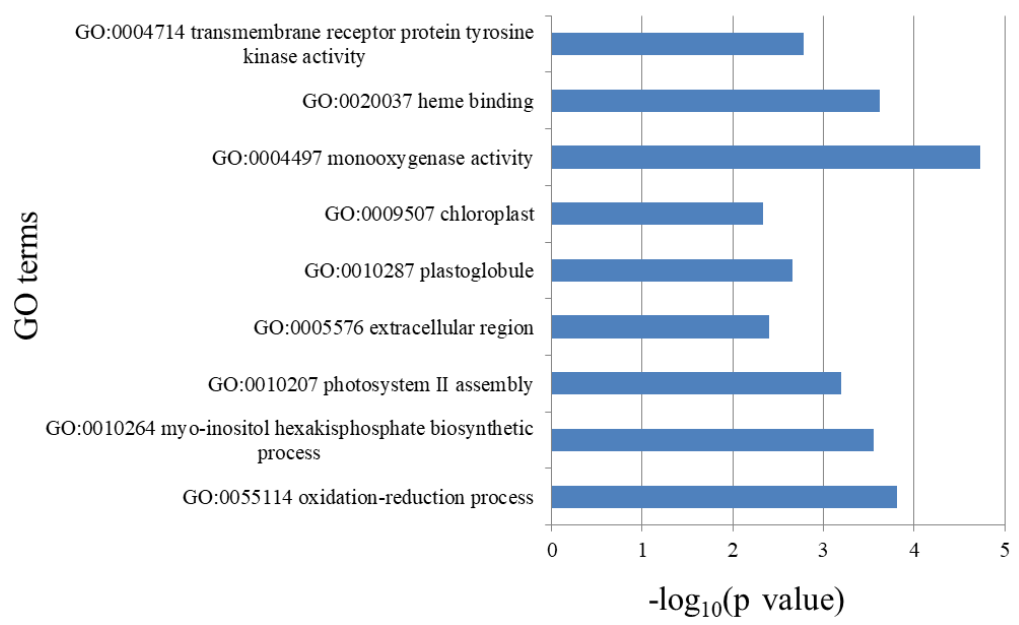

Figure $3 \mathrm{GO}$ terms significantly enriched in biological processes, cellular components, and molecular functions.

AFPs included 1 thaumatin-like protein $(T L P)$, 1 late-embryogenesis-abundant protein $(L E A)$ and 1 early-response to dehydration protein $(E R D)$ that were up-regulated. The 9 genes related to the carbohydrate metabolic pathway included 2 galactosidases (all down-regulated), 2 amylases (all down-regulated), 2 galactinol synthases (all up-regulated), 2 inositol synthases (up-regulated) and 1 monosaccharide transporter gene (up-regulated). Finally, the 10 genes related to the osmotic regulation included 2 proline synthases (all up-regulated) and 8 peroxidases ( 3 up-regulated and 5 down-regulated). In general, the number of down-regulated proteins exceeded that of up-regulated proteins.

\section{Cold-responsive transcription factors (TF)}

A total of $12 \mathrm{TF}$ families were identified among all the genes in C. japonica var. decumbens (Table 6). The majority of TFs belong to the $A P 2 /$ EREBP, WRKY, MYB, zinc finger, HB (Homeobox), $b H L H$ and NAC families. Among these TFs, 16 genes were up-regulated and 10 genes were down-regulated. The HB family was the most enriched TF family, with 3 genes being up-regulated and 2 being down-regulated. 58
There were 4 genes in the zinc finger family (3 up-regulated and 1 down-regulated), 4 genes in the MYB family (3) up-regulated and 1 down-regulated), 3 genes in the WRKY family (all down-regulated), 2 genes in the $P H D$ family (all down-regulated) and 2 genes in the COL family (all up-regulated). In addition, 1 gene in the $N A C$ family, 1 gene in the $b H L H$ family, 1 gene in the TCP family, 1 gene in the CBF family and 1 gene in the $C O L$ family were up-regulated, 1 gene in the $A P 2 / E R F$ family was down-regulated.

\section{Discussion}

\section{GO annotation analysis of DEGs}

We explored low-temperature-driven changes in the highly cold-tolerant $C$. japonica var. decumbens through transcriptomic analysis. In our transcriptome analysis, we observed that the numbers of DEGs at five different temperatures of cold stress were only partly overlapping, further suggesting a diverse and complex mechanism in C. japonica var. decumbens. Through GO annotation analysis of DEGs, unigenes were divided into three categories: biological processes, cellular components, and molecular functions.

These GO terms contain a variety of genes that regulate cold signaling mechanisms, such as signal transduction (GO:0004714 and GO:0055114), the ROS (reactive oxygen spe- 
Table 4 GeneID and expression patterns of DEGs in C. japonica var. decumbens in response to cold stress - cold sensor or signal transduction genes

\begin{tabular}{|c|c|c|c|}
\hline Gene ID & Annotation & GO ID & Expression pattern* \\
\hline BMK_Unigene_059089 & $\begin{array}{l}\text { kinesin-like calmodulin- } \\
\text { binding protein homolog }\end{array}$ & $\begin{array}{l}0003777,0005516, \\
0005524,0005871, \\
0005886,0006200, \\
0007018,0008017, \\
0009846,0010091, \\
0016491,0016887, \\
0055114\end{array}$ & $\mathrm{~B}$ \\
\hline BMK_Unigene_068489 & $\begin{array}{l}\text { phospholipase D delta- } \\
\text { like }\end{array}$ & $\begin{array}{l}0004630,0005509, \\
0005773,0005886, \\
0009409,0012501, \\
0016042, \\
0046473,0070290\end{array}$ & B \\
\hline BMK_Unigene_003106 & $\begin{array}{l}\text { Phospholipase D beta } 1 \\
\text { isoform } 2\end{array}$ & 0016787 & A \\
\hline BMK_Unigene_030195 & $\begin{array}{l}\text { probable calcium- } \\
\text { binding protein CML13 }\end{array}$ & 0005509 & B \\
\hline BMK_Unigene_053123 & $\begin{array}{l}\text { probable calcium- } \\
\text { binding protein CML17 }\end{array}$ & 0005509 & $\mathrm{~A}$ \\
\hline BMK_Unigene_031543 & $\begin{array}{l}\text { CBL-interacting protein } \\
\text { kinase } 14\end{array}$ & $\begin{array}{l}0004683,0005524 \\
0006468,0007165\end{array}$ & A \\
\hline BMK_Unigene_026895 & $\begin{array}{l}\text { CBL-interacting serine/ } \\
\text { threonine-protein kinase } \\
\text { 6-like }\end{array}$ & $\begin{array}{l}0004683,0005524, \\
0006468,0007275, \\
0009414,0010118, \\
0010540,0019722, \\
0042538\end{array}$ & $\mathrm{~A}$ \\
\hline BMK_Unigene_032085 & $\begin{array}{l}\text { CBL-interacting protein } \\
\text { kinase 5-like }\end{array}$ & $\begin{array}{l}0004674,0005524, \\
0005829,0006468, \\
0007165,0009737\end{array}$ & $\mathrm{~A}$ \\
\hline BMK_Unigene_064870 & $\begin{array}{l}\text { CBL-interacting protein } \\
\text { kinase } 18\end{array}$ & $\begin{array}{l}0004674,0005524, \\
0006468,0007165\end{array}$ & $\mathrm{~A}$ \\
\hline BMK_Unigene_074275 & $\begin{array}{l}\text { CBL-interacting protein } \\
\text { kinase } 8 \text { isoform X3 }\end{array}$ & $\begin{array}{l}0004683,0005524 \\
0006468,0007165\end{array}$ & $\mathrm{~B}$ \\
\hline BMK_Unigene_003136 & $\begin{array}{l}\text { CBL-interacting serine/ } \\
\text { threonine-protein kinase, } \\
\text { putative }\end{array}$ & $\begin{array}{l}0004683,0005524, \\
0006468,0009268, \\
0009611,0009620, \\
0009695,0009723, \\
0009738,0009753, \\
0010118,0019722, \\
0042802\end{array}$ & $\mathrm{~A}$ \\
\hline BMK_Unigene_048017 & $\begin{array}{l}\text { cysteine-rich receptor- } \\
\text { like protein kinase 2-like } \\
\text { isoform X1 }\end{array}$ & $\begin{array}{l}0004674,0004714, \\
0005524,0006468\end{array}$ & $\mathrm{~B}$ \\
\hline
\end{tabular}


Table 4 (continuation)

\begin{tabular}{lllc}
\hline Gene ID & Annotation & GO ID & Expression pattern* \\
\hline BMK_Unigene_052658 & $\begin{array}{l}\text { cysteine-rich receptor- } \\
\text { like protein kinase 2 }\end{array}$ & $\begin{array}{l}\text { 0004674, 0005524, } \\
0006468\end{array}$ & A \\
\hline BMK_Unigene_083562 & $\begin{array}{l}\text { cysteine-rich receptor- } \\
\text { like protein kinase 10 }\end{array}$ & 0016772 & A \\
\hline
\end{tabular}

Note. *A: up-regulated in response to cold stress, B: down-regulatedin response to cold stress.

Table 5 GeneID and expression patterns of DEGs in C. japonica var. decumbens in response to cold stress - genes related to the stabilization of the plasma membrane and osmosensing response

\begin{tabular}{|c|c|c|c|}
\hline Gene ID & Annotation & GO ID & Expression pattern* \\
\hline BMK_Unigene_082277 & $\begin{array}{l}\text { late embryogenesis } \\
\text { abundant protein } 3 \mathrm{~L}-1\end{array}$ & 0006950 & A \\
\hline BMK_Unigene_053695 & $\begin{array}{l}\text { Pterin-4-alpha- } \\
\text { carbinolamine } \\
\text { dehydratase } 1 \text { isoform } 1\end{array}$ & $\begin{array}{l}0006098,0006364, \\
0006729,0008124, \\
0009073,0009902, \\
0010027,0010207, \\
0016226,0035304, \\
0042793\end{array}$ & A \\
\hline BMK_Unigene_035417 & Thaumatin-like protein & $\begin{array}{l}0005576,0005773, \\
0006952,0009607\end{array}$ & B \\
\hline BMK_Unigene_032442 & $\begin{array}{l}\text { Monosaccharide-sensing } \\
2 \text {-like protein }\end{array}$ & $\begin{array}{l}0005886,0008643, \\
0009624,0009705, \\
0016021,0022891, \\
0032440,0055085, \\
0055114\end{array}$ & A \\
\hline BMK_Unigene_014209 & $\begin{array}{l}\text { inositol-tetrakisphosphate } \\
\text { 1-kinase 1-like }\end{array}$ & $\begin{array}{l}0000287,0005524, \\
0005622,0016310, \\
0032957,0047325, \\
0052725,0052726\end{array}$ & A \\
\hline BMK_Unigene_021231 & $\begin{array}{l}\text { inositol-3-phosphate } \\
\text { synthase }\end{array}$ & $\begin{array}{l}0004512,0005737, \\
0006021,0008654\end{array}$ & A \\
\hline BMK_Unigene_063789 & $\begin{array}{l}\text { Proline synthase co- } \\
\text { transcribed bacterial } \\
\text { homolog protein-like }\end{array}$ & 0006744,0010264 & A \\
\hline BMK_Unigene_090251 & $\begin{array}{l}\text { proline iminopeptidase } \\
\text { isoform X3 }\end{array}$ & $\begin{array}{l}0004177,0005829 \\
0006508,0009507\end{array}$ & B \\
\hline BMK_Unigene_098571 & alpha-galactosidase-like & 0005975,0052692 & $\mathrm{~B}$ \\
\hline BMK_Unigene_053108 & Beta-galactosidase & $\begin{array}{l}0003676,0004553, \\
0044260,0090304\end{array}$ & B \\
\hline BMK_Unigene_026906 & alpha-amylase & $\begin{array}{l}\text { 0004556, 0005509, } \\
0005975\end{array}$ & B \\
\hline
\end{tabular}


Table 5 (continuation)

\begin{tabular}{|c|c|c|c|}
\hline Gene ID & Annotation & GO ID & Expression pattern* \\
\hline BMK_Unigene_053508 & beta-amylase 2 & $\begin{array}{l}0000272,0003700, \\
0005634,0006355, \\
0010048,0016161, \\
0043169,0048831\end{array}$ & B \\
\hline BMK_Unigene_057052 & galactinol synthase 2-like & 0006757 & A \\
\hline BMK_Unigene_082020 & galactinol synthase & $\begin{array}{l}0005737,0006012, \\
0046872,0047216\end{array}$ & A \\
\hline BMK_Unigene_014922 & $\begin{array}{l}\text { putative L-ascorbate } \\
\text { peroxidase } 6 \text { isoform X2 }\end{array}$ & 0004601 & A \\
\hline BMK_Unigene_032980 & peroxidase 55 -like & $\begin{array}{l}0004601,0006979, \\
0020037,0046872, \\
0055114\end{array}$ & B \\
\hline BMK_Unigene_016454 & peroxidase 47 & $\begin{array}{l}0004601,0006598, \\
0006979,0009698, \\
0010167,0015706, \\
0020037,0042398, \\
0046872,0055114\end{array}$ & A \\
\hline BMK_Unigene_050046 & peroxidase N1-like & $\begin{array}{l}0004601,0005618, \\
0006979,0016020, \\
0020037,0045730, \\
0046872,0048046, \\
0050832,0055114\end{array}$ & B \\
\hline BMK_Unigene_052334 & $\begin{array}{l}\text { Peroxidase } 73 \text { precursor, } \\
\text { putative }\end{array}$ & $\begin{array}{l}0004601,0006979, \\
0020037,0046872, \\
0055114\end{array}$ & A \\
\hline BMK_Unigene_071000 & Peroxidase 72 & $\begin{array}{l}0004601,0005618, \\
0006979,0020037, \\
0046872,0051707, \\
0055114\end{array}$ & B \\
\hline BMK_Unigene_073145 & peroxidase 52-like & $\begin{array}{l}0004601,0006979, \\
0020037,0046872, \\
0055114\end{array}$ & B \\
\hline BMK_Unigene_016454 & peroxidase 47 & $\begin{array}{l}0004601,0006598, \\
0006979,0009698, \\
0010167,0015706, \\
0020037,0042398, \\
0046872,0055114\end{array}$ & A \\
\hline
\end{tabular}

Note. ${ }^{*}$ A: up-regulated in response to cold stress, B: down-regulated in response to cold stress

cies) system (GO:0055114), and the plasma membrane (GO:0010264 and GO:0010207). In general, GO term enrichment was similar among treatments. Thus, despite both unique and overlapping DEGs were detected among treatments, the resulting gene functions seem to be similar. Similar GO term enrichment was also revealed in a study that investigated a cold 
Table 6 GeneID and expression patterns of DEGs in C. japonica var. decumbens in response to cold stress - cold-responsive transcription factors (TF)

\begin{tabular}{|c|c|c|c|}
\hline Gene ID & Annotation & GO ID & Expression pattern* \\
\hline BMK_Unigene_022693 & CBF-like protein & $\begin{array}{l}0006351,0006950, \\
0009628\end{array}$ & A \\
\hline BMK_Unigene_097492 & $\begin{array}{l}\text { CONSTANS interacting } \\
\text { protein } 2 \mathrm{a}\end{array}$ & $\begin{array}{l}0003700,0016602, \\
0043565,0045893, \\
0046982\end{array}$ & A \\
\hline BMK_Unigene_102040 & $\begin{array}{l}\text { putative CONSTANS-like } \\
\text { protein }\end{array}$ & $\begin{array}{l}0003677,0003700, \\
0005634,0006355, \\
0007623,0008270, \\
0009909,0010018, \\
0010229,0048571, \\
0048572\end{array}$ & A \\
\hline BMK_Unigene_035960 & $\begin{array}{l}\text { Probable WRKY } \\
\text { transcription factor } 75\end{array}$ & $\begin{array}{l}0003700,0006355 \\
0043565\end{array}$ & $\mathrm{~B}$ \\
\hline BMK_Unigene_060242 & $\begin{array}{l}\text { probable WRKY } \\
\text { transcription factor } 17\end{array}$ & 0003677 & $\mathrm{~B}$ \\
\hline BMK_Unigene_071976 & $\begin{array}{l}\text { probable WRKY } \\
\text { transcription factor } 75\end{array}$ & $\begin{array}{l}0003700,0006355, \\
0043565\end{array}$ & B \\
\hline BMK_Unigene_083366 & MYB & 0003677,0003682 & B \\
\hline BMK_Unigene_101671 & MYB transcription factor 1 & 0003677,0003682 & $\mathrm{~A}$ \\
\hline BMK_Unigene_025250 & $\begin{array}{l}\text { Myb domain protein } 17 \\
\text { isoform } 2\end{array}$ & $\begin{array}{l}0003677,0003682, \\
0003700,0006355, \\
0009909,0010033, \\
0048443,1901700\end{array}$ & A \\
\hline BMK_Unigene_033735 & $\begin{array}{l}\text { transcription factor } \\
\text { MYB44-like }\end{array}$ & 0005488 & A \\
\hline BMK_Unigene_009682 & $\begin{array}{l}\text { NAC transcription factor- } \\
\text { like protein }\end{array}$ & $\begin{array}{l}0003677,0003700 \\
0006355,0007275\end{array}$ & A \\
\hline BMK_Unigene_053238 & $\begin{array}{l}\text { AP2-like ethylene- } \\
\text { responsive transcription } \\
\text { factor At1g16060 isoform } \\
\text { X1 }\end{array}$ & $\begin{array}{l}0003677,0003700 \\
0005634,0006355\end{array}$ & $\mathrm{~B}$ \\
\hline BMK_Unigene_014504 & $\begin{array}{l}\text { transcription factor } \\
\text { bHLH147 isoform X1 }\end{array}$ & 0046983 & A \\
\hline BMK_Unigene_056742 & $\begin{array}{l}\text { RING/FYVE/PHD zinc } \\
\text { finger superfamily protein }\end{array}$ & $\begin{array}{l}0004842,0008270, \\
0016567\end{array}$ & $\mathrm{~B}$ \\
\hline BMK_Unigene_082349 & $\begin{array}{l}\text { PHD finger protein ALFIN- } \\
\text { LIKE 1-like }\end{array}$ & $\begin{array}{l}0006355,0008270 \\
0042393\end{array}$ & B \\
\hline BMK_Unigene_094929 & transcription factor TCP14 & 0050896 & A \\
\hline BMK_Unigene_031365 & $\begin{array}{l}\text { homeobox-leucine zipper } \\
\text { protein ROC3 }\end{array}$ & $\begin{array}{l}0003700,0005634 \\
0006355,0043565\end{array}$ & A \\
\hline
\end{tabular}


Table 6 (continuation)

\begin{tabular}{|c|c|c|c|}
\hline Gene ID & Annotation & GO ID & Expression pattern* \\
\hline BMK_Unigene_044390 & $\begin{array}{l}\text { Homeobox-leucine zipper } \\
\text { protein REVOLUTA }\end{array}$ & $\begin{array}{l}0003700,0005634, \\
0006355,0007155, \\
0008289,0009855, \\
0009944,0009956, \\
0009965,0010051, \\
0010072,0010075, \\
0010090,0016049, \\
0043565,0045010, \\
0045595,0048439, \\
0048519,0048765, \\
0071555\end{array}$ & $\mathrm{~B}$ \\
\hline BMK_Unigene_088909 & $\begin{array}{l}\text { Homeobox protein, putative } \\
\text { isoform } 2\end{array}$ & $\begin{array}{l}0000976,0003700 \\
0005634,0006355\end{array}$ & A \\
\hline BMK_Unigene_098580 & $\begin{array}{l}\text { homeobox leucine zipper } \\
\text { family protein }\end{array}$ & 0006351,0043565 & $\mathrm{~B}$ \\
\hline BMK_Unigene_032483 & $\begin{array}{l}\text { MADS-box transcription } \\
\text { factor protein } 1\end{array}$ & $\begin{array}{l}0003677,0003700, \\
0005634,0006355, \\
0046983\end{array}$ & A \\
\hline BMK_Unigene_009946 & $\begin{array}{l}\text { putative zinc finger protein } \\
\text { At1g68190 }\end{array}$ & 0005622,0008270 & A \\
\hline BMK_Unigene_017442 & $\begin{array}{l}\text { zinc finger protein WIP3 } \\
\text { isoform X1 }\end{array}$ & $\begin{array}{l}0003676,0005634, \\
0046872\end{array}$ & $\mathrm{~B}$ \\
\hline BMK_Unigene_090331 & $\begin{array}{l}\text { B-box zinc finger protein } 19 \\
\text { isoform X1 }\end{array}$ & 0005622,0008270 & A \\
\hline BMK_Unigene_002000 & B-box zinc finger protein 25 & 0005622,0008270 & A \\
\hline
\end{tabular}

Note. *A: up-regulated in response to cold stress, B: down-regulated in response to cold stress

acclimation-related transcriptome of $C$. japonica ( $\mathrm{Li}$ et al. 2016), and in cold-related transcriptome studies with other woody species such as Hevea brasiliensis (Cheng et al. 2018), Eucalyptus nitens (Gaete-Loyola et al. 2017), or Prunus dulcis (Hosseinpour et al. 2018).

Dozens of cold related genes with known function in other model plants were found in this differential expression list, including cold sensor or signal transduction genes, cold responsive transcription factor genes, plasma membrane stabilization related genes and osmosensing-responsive genes. These genes are described in detail below.

\section{Cold sensor or signal transduction genes}

Signal transduction pathways play pivotal roles in the response to low-temperature stress (Janská et al. 2010). Increasing evidence has shown that calcium is an important second messenger in a low-temperature signal transduction pathway involved in regulating the cold-acclimation response (Thomashow 1999). Cold stress could activate calcium channels to increase the cytosolic calcium level and then trigger phospholipase $\mathrm{C}$ and $\mathrm{D}$, producing phosphatidic acid. Phosphatidic acid is proposed as a membrane-based secondary messenger (Vergnolle et al. 2005; Munnik 2001). Protein phosphorylation/dephosphorylation is known to play 
a role in signal transduction during cold acclimation. In addition, plant protein kinases belong to a large superfamily, some of which play a central role in cellular signaling, such as CIPK or CRK.

In the signal transduction cascade, possible members of the pathways include genes encoding calcium-binding proteins, such as CIPK18, and CRK2 (Table 4), which are induced by cold stress, participate in signal perception and transmission to modulate the expression of stress-regulated genes and thus generate a suitable response (Abbasi et al. 2004; Gong et al. 2002). The findings suggest that these early response genes may provide initial protection and regulate gene expression upon exposure to cold stress.

\section{Genes related to the stabilization of the plas- ma membrane and osmosensing response}

Under freezing temperatures, membranes must be kept fluid to maintain the structural stabilization of the plasma membrane during the cold-stress process, and some protein function as inhibitors to regulate the activity of ice nucleators. These proteins are so-called AFPs, such as $\beta$-1,3-glucanase-like proteins (GLPs), $E R D, T L P s$, polygalacturonase inhibitor proteins (PGIPS) and LEAs.

The stabilization of the plasma membranes is also related to the osmotic equilibrium. In order to maintain osmotic balance, plants accumulate a range of compatible solutes, including soluble sugars (saccharose, trehalose, rafinose), sugar alcohols (ribitol, inositol, sorbitol), and low-molecular weight compounds (such as proline, glycine betaine, glutamic acid) as cryoprotectant molecules in response to cold stress (Gao et al. 2003; Uemura et al. 2006). Cold temperatures also cause plants to undergo oxidative stress induced by reactive oxygen species. Therefore, antioxidant enzymes (ascorbate peroxidase, glutathione reductase, superoxide dismutase, and others) are activated to participate in free radical scav- enging. The activity of antioxidant enzymes is induced by low temperature and plays an important role in the recovery of damage caused by freezing (Renaut et al. 2006).

The plasma membrane is believed to be a primary site of injury from freezing in plants. In our study, three $A F P S$ were up-regulated indicating that during the cold-stress process, C. japonica var. decumbens becomes tolerant to freezing temperatures by enhancing the membrane stability. Galactinol synthase, inositol-3-phosphate synthase and beta-amylase 2 (BAM2) (Table 5) were regulated by cold stress suggesting that the carbohydrate metabolic pathway also plays a critical role in $C$. japonica var. decumbens during the cold-stress response. As described above, woody plants can resist low temperatures when the starch concentration is reduced, and the soluble sugar concentration is increased in the plant tissue (Dhanaraj et al. 2004).

\section{Cold-responsive transcription factors (TF)}

TFs have been shown to play a key role in regulating gene expression under various environmental stresses (Chen and Zhu 2004). Therefore, many TFs are regulated by low temperature, indicating the complexity of the cold regulation network.

We noted that these TFs constitute a significant proportion of stress-inducible genes, suggesting that gene transcriptional regulation of stress responses is a crucial mechanism for stress adaptation in C. japonica var. decumbens. Some members of the same TF family were induced by cold, whereas others were repressed. A well-characterized TF (ICE1) in Arabidopsis (Chinnusamy et al. 2003) was also detected in C. japonica var. decumbens and was shown to be constitutively expressed across the cold stress conditions; this TF probably has a conserved function in cold signaling. AP2/ERF TFs have been implicated in hormone, sugar and redox signaling pathways in the context of abiotic stresses, such as cold 
and drought stress (Dietz et al. 2010). Members of the $H B, b H L H$ and $M Y B$ TF families that are major regulators of ABA-responsive gene expression (Lata and Prasad 2011; Li et al. 2012; Zhao et al. 2011) respond differently to cold stress. A number of TFs, including diverse family members, such WRKY and $M A D S$, were also differentially expressed upon exposure to cold-stress conditions.

\section{Conclusion}

In summary, $C$. japonica var. decumbens may have rapid and complex cold stress signal sensing, transduction and response mechanisms. The low temperature signal may be sensed by the cell membrane receptor and then transformed into $\mathrm{Ca}^{2+}$, ROS, osmotic stress and other signals. Through the transduction of kinases or direct activation of stress-sensitive TFs, the downstream cold response genes could be further activated to synthesize ROS scavenging enzymes and osmotic material and improve the membrane protective ability, and peroxidase balance to complete the cold adaptation process.

The transcriptional resources generated in this study can be applied for the identification of functional polymorphisms in these expressional candidate genes for cold tolerance. Specifically, these resources can be used for the development of Single Nucleotide Polymorphism (SNP) markers for association analyses with cold tolerance in natural and experimental populations, for marker-assisted breeding of low temperature tolerant $C$. japonica and the application of new breeding technologies.

Specifically, future research will focus on the expression and regulation of signaling, protein kinases, transcription factors and antifreeze proteins. Therefore, our transcriptional overview will prove to be very useful, not only for understanding molecular networks that regulate cold stress, but also for exploring cold-tolerance genes that could improve the cold tolerance of Camellia.

\section{Acknowledgments}

This work was supported by the project 948 of the state forestry administration (2011-4-41), China. Thanks to the Forestry Research Base of Henan Agricultural University for providing land.

\section{References}

Abbasi F., Onodera H., Toki S., Tanaka H., Komatsu S., 2004. OsCDPK13, a calcium-dependent protein kinase gene from rice, is induced by cold and gibberellin in rice leaf sheath. Plant Molecular Biology 55(4):541552. DOI: $10.1007 / \mathrm{s} 11103-004-1178-y$

Altschul S.F., Madden T.L., Schaffer A.A., Zhang J, Zhang Z, Miller W, et al. 1997. Gapped BLAST and PSIBLAST: a new generation of protein database search programs. Nucleic Acids Research 25(17):3389-3402. DOI: $10.1093 /$ nar/25.17.3389

Apweiler R., Bairoch A., Wu C.H., Barker W.C., Boeckmann B., Ferro S. 2004. UniProt: the Universal Protein knowledgebase. Nucleic Acids Research 32: D115-119. DOI: 10.1093/nar/gkh131

Ashburner M., Ball C.A., Blake J.A., Botstein D., Butler H., Cherry J.M., 2000. Gene ontology: tool for the unification of biology. The Gene Ontology Consortium. Nature Genetics 25(1):25-29. DOI: 10.1038/75556

Audic S., Claverie JM., 1997. The significance of digital gene expression profiles. Genome Research 7(10):986995. DOI: $10.1101 /$ gr.7.10.986

Chen W.J., Zhu T., (2004) Networks of transcription factors with roles in environmental stress response. Trends in Plant Scince 9(12):591-596. DOI: 10.1016/j. tplants.2004.10.007

Cheng H., Chen X., Fang J., An Z., Hu Y. and Huang. H., 2018. Comparative transcriptome analysis reveals an early gene expression profile that contributes to cold resistance in Hevea brasiliensis (the Para rubber tree). Tree Physiology 38: 1409-1423. DOI: 10.1093/treephys/tpy014

Chinnusamy V., Ohta M., Kanrar S., Lee B.H., Hong X., Agarwal M., Zhu J.K., (2003) ICE1: a regulator of cold-induced transcriptome and freezing tolerance in Arabidopsis. Genes Development 17(8): 1043-1054. DOI: $10.1101 / \mathrm{gad} .1077503$

Deng Y., Li J., Wu S., Zhu Y., Chen Y., He F., 2006. Integrated $\mathrm{nr}$ Database in protein annotation system and its localization. Computer Engineering 32:71-76.

Dhanaraj A.L., Slovin J.P., Rowland L.J., 2004. Analysis of gene expression associated with cold acclimation in blueberry floral buds using expressed sequence tags. Plant Science 166 (4): 863-872. DOI: 10.1016/j.plantsci.2003.11.013 
Dietz K. J., Vogel M. O., Viehhauser A., 2010. AP2/ EREBP transcription factors are part of gene regulatory networks and integrate metabolic, hormonal and environmental signals in stress acclimation and retrograde signaling. Protoplasma 245(1-4):3-14. DOI: $10.1007 /$ s00709-010-0142-8

Djebali S., Davis C.A., Merkel A., Dobin A., Lassmann T., Mortazavi A., 2012. Landscape of transcription in human cells. Nature 489(7414): 101-108. DOI: 10.1038/ nature 11233

Eddy S.R., 1998. Profile hidden Markov models. Bioinformatics 14(9): 755-763. DOI: 10.1093/bioinformatics/14.9.755

Finn R.D., Bateman A., Clements J., Coggill P., Eberhardt R. Y., Eddy S. R., 2014. Pfam: the protein families database. Nucleic Acids Research 42: D222-230. DOI: 10.1093/nar/gkt1223

Gaete-Loyola, J., Lagos C., Beltrán M.F., Valenzuela S., Emhart V., Fernández M., 2017. Transcriptome profiling of Eucalyptus nitens reveals deeper insight into the molecular mechanism of cold acclimation and deacclimation process. Tree Genetics and Genomics 13: 37. DOI: $10.1007 / \mathrm{s} 11295-017-1121-4$

Gai J., 2000. Methods of experimental statistics. Beijing: China Agriculture Press: 211-212.

Gao M.J., Schafer U.A., Parkin I.A., Hegedus D.D., Lydiate D. J., Hannoufa A., 2003. A novel protein from Brassica napus has a putative KID domain and responds to low temperature. Plant Journal 33(6): 1073-1086. DOI: 10.1046/j.1365-313X.2003.01694.X

Gong ., Gong Z., Guo Y., Chen X., Zhu J.K., 2002. Biochemical and functional characterization of PKS11, a novel Arabidopsis protein kinase. Journal of Biological Chemistry 277(31): 28340-28350. DOI: $10.1074 / \mathrm{jbc}$. M107719200

Grabherr M.G., Haas B.J., Yassour M., Levin J.Z., Thompson D.A., Amit I., 2011. Full-length transcriptome assembly from RNA-Seq data without a reference genome. Nature Biotechnology 29(7):644-652. DOI: 10.1038/nbt.1883

Guo Y., Sheng Q., Li J., Ye F., Samuels D.C., Shyr Y., 2013. Large scale comparison of gene expression levels by microarrays and RNAseq using TCGA data. PloS One 8(8): e71462. DOI: 10.1371/journal.pone.0071462

Hosseinpour B., Sepahvand S., Kamali Aliabad K., Bakhtiarizadeh M., Imani A., Assareh R., 2018. Transcriptome profiling of fully open flowers in a frost-tolerant almond genotype in response to freezing stress. Molecular Genetics and Genomics 293: 151-163. DOI: 10.1007/s00438-017-1371-8

Janská A., Marík P., Zelenková S., Ovesná J., 2010. Cold stress and acclimation - what is important for metabolic adjustment? Plant Biology 12(3):395-405. DOI: 10.1111/j.1438-8677.2009.00299.x

Kanehisa M., Goto S., Kawashima S., Okuno Y., Hattori M., 2004. The KEGG resource for deciphering the genome. Nucleic Acids Research 32:D277-280. DOI: 10.1093/nar/gkh063
Kim S., Jung E., Shin S., 2012. Anti-inflammatory activity of Camellia japonica oil. BMB Rep. 45:177-182. DOI: 10.5483/BMBRep.2012.45.3.177

Kondo K. 2008. Cytological studies in cultivated species of Camellia: I. diploid species and their hybrids. Japanese Journal of Breeding 27: 28-38. DOI: 10.1270/ jsbbs1951.27.28

Koonin E.V., Fedorova N.D., Jackson J.D., Jacobs A.R., Krylov D.M., Makarova K.S., 2004. A comprehensive evolutionary classification of proteins encoded in complete eukaryotic genomes. Genome Biology 5(2):R7. DOI: $10.1186 / \mathrm{gb}-2004-5-2-\mathrm{r} 7$

Langmead B., Trapnell C., Pop M., Salzberg S.L., 2009. Ultrafast and memory-efficient alignment of short DNA sequences to the human genome. Genome Biology. 10(3): R25. DOI: 10.1186/gb-2009-10-3-r25

Lata C., Prasad M., 2011. Role of DREBs in regulation of abiotic stress responses in plants. Journal of Experimental Botany 62(14): 4731-4748. DOI: 10.1093/jxb/ err210

Leng N., Dawson J.A., Thomson J.A., Ruotti V., Rissman A.I., Smits B.M., 2013. EBSeq: an empirical Bayes hierarchical model for inference in RNA-seq experiments. Bioinformatics 29(8): 1035-1043. DOI: 10.1093/bioinformatics/btt087

Li B., Dewey C.N., 2011. RSEM: accurate transcript quantification from RNA-Seq data with or without a reference genome. BMC Bioinformatics 12:323. DOI: 10.1186/1471-2105-12-323

Li B., Takahashi D., Kawamura Y., Uemura M., 2012. Comparison of plasma membrane proteomic changes of Arabidopsis suspension-cultured cells (T87 Line) after cold and ABA treatment in association with freezing tolerance development. Plant and Cell Physiology 53(3): 543-554. DOI: 10.1093/pcp/pcs010

Li Q., Lei S., Du K., Li L., Pang X., Wang Z., 2016. RNAseq based transcriptomic analysis uncovers $\alpha$-linolenic acid and jasmonic acid biosynthesis pathways respond to cold acclimation in Camellia japonica. Scientific Reports 6: 36463. DOI: $10.1038 /$ srep36463

Lin M.R., 1994. The trees of the Japanese. Japan, The Society For Truth And Light, pp. 482-483

Lohse M., Nagel A., Herter T., May P., Schroda M., Zrenner R., 2014. Mercator: a fast and simple web server for genome scale functional annotation of plant sequence data. Plant, Cell \& Environment 37(5): 1250-1258. DOI: $10.1111 /$ pce. 12231

Min T.L., Zhang W.J., 1996. The evolution and distribution of genus Camellia. Acta Botanica Yunnanica 18 (1): 1-13.

Mortazavi A., Williams B.A., McCue K., Schaeffer L., Wold B., 2008. Mapping and quantifying mammalian transcriptomes by RNA-Seq. Nature Methods 5(7): 621-628. DOI: 10.1038/nmeth.1226

Munnik T., 2001. Phosphatidic acid: an emerging plant lipid second messenger. Trends in Plant Science 6(5): 227-233. DOI: 10.1016/S1360-1385(01)01918-5

Piao M.J., Yoo E.S., Koh Y.S., 2011. Antioxidant effects 
of the ethanol extract from flower of Camellia japonica via scavenging of reactive oxygen species and induction of antioxidant enzymes. International Journal of Molecular Sciences 12: 2618-2630. DOI: 10.3390/ ijms 12042618

Reiner A., Yekutieli D., Benjamini Y., 2003. Identifying differentially expressed genes using false discovery rate controlling procedures. Bioinformatics 19(3): 368-375. DOI: $10.1093 /$ bioinformatics/btf877

Renaut J., Hausman J.F., Wisniewski M., 2006. Proteomics and low temperature studies: bridging the gap between gene expression and metabolism. Physiologia Plantarum 126 (1): 97-109. DOI: 10.1111/j.13993054.2006.00617.x

Tan H., Huang H., Tie M., 2016. Transcriptome profiling of two Asparagus Bean (Vigna unguiculata subsp. sesquipedalis) cultivars differing in chilling tolerance under cold stress. Plos One 11(3):e0151105. DOI: 10.1371/journal.pone.0151105

Tatusov R.L., Galperin M.Y., Natale D.A., Koonin E.V., 2000. The COG database: a tool for genome-scale analysis of protein functions and evolution. Nucleic Acids Research 28(1): 33-36. DOI: 10.1093/nar/28.1.33

Thomashow M.F., 1999. Plant cold acclimation: freezing tolerance genes and regulatory mechanisms. Annual Review of Plant Physiology and Plant Molecular Biology 50: 571-599. DOI: 10.1146/annurev.arplant.50.1.571

Trapnell C., Williams B.A., Pertea G., Mortazavi A., Kwan G., van Baren M.J., 2010. Transcript assembly and quantification by RNA-Seq reveals unannotated transcripts and isoform switching during cell differentiation. Nature Biotechnology 28(5): 511-515. DOI: 10.1038/nbt. 1621

Uemura M., Tominaga Y., Nakagawara C., Shigematsu S., Minami A., Kawamura Y., 2006. Responses of the plasma membrane to low temperatures. Physiology Plant 126(1): 81-89. DOI: 10.1111/j.1399-3054.2005.00594.x

Vergnolle C., Vaultier M.N., Taconnat L., Renou J.P., Kader J.C., Zachowski A., Ruelland E., 2005. The cold-induced early activation of phospholipase $\mathrm{C}$ and $\mathrm{D}$ pathways determines the response of two distinct clusters of genes in Arabidopsis cell suspensions. Plant Physiology 139: 1217-1233. DOI: 10.1104/pp.105.068171

Wang X.C., Zhao Q.Y., Ma C.L., 2013. Global transcriptome profiles of Camellia sinensis during cold acclimation. Bmc Genomics 14(1): 415. DOI: 10.1186/14712164-14-415

Wang H.B., Cheng L.L., Chang Y.S., 2016. Physiological and transcriptome response of apple dwarfing rootstock to cold stress and cold-resistant genes screening. Acta Horticulturae Sinica 43(8): 1437-1451

Xu Y., Chen F.., 2008. The LT50 and cold tolerance adaptability of Chrysanthemum during a natural drop in temperature. Acta Horticulturae Sinica 35(4): 559-564

Xu W., Li R., Zhang N., Ma F., Jiao Y., Wang Z., 2014. Transcriptome profiling of Vitis amurensis, an extremely cold-tolerant Chinese wild Vitis species, reveals candidate genes and events that potentially connected to cold stress. Plant Molecular Biology 86: 527-541. DOI: 10.1007/s11103-014-0245-2

Yoshikawa M., Morikawa T., Asao Y., Fujiwara E., Nakamura S., Matsuda H., 2007. Medicinal flowers. XV. The structures of noroleanane- and oleanane-type triterpene oligoglycosides with gastroprotective and platelet aggregation activities from flower buds of Camellia japonica. Chemical and Pharmaceutical Bulletin (Tokyo) 55:606-612. DOI: 10.1248/cpb.55.606

Zhao Y., Zhou Y., Jiang H., Li X., Gan D., Peng X., Zhu S., Cheng B., 2011. Systematic analysis of sequences and expression patterns of drought-responsive members of the HD-Zip gene family in maize. Plos One 6(12): e28488. DOI: 10.1371/journal.pone.0028488

\section{Supporting Information}

The online version of the article includes Supporting Information:

Table S1. GO annotations for DEGs in $C$. japonica var. decumbens in response to cold stress: cold sensor or signal transduction genes

Table S2. GO annotations for DEGs in $C$. japonica var. decumbens in response to cold stress: genes related to the stabilization of the plasma membrane and osmosensing response

Table S3. GO annotations for DEGs in $C$. japonica var. decumbens in response to cold stress: cold-responsive transcription factors (TF) 
